\title{
Nutritional Potential of Co-products of Two Species of Benin Cucurbits
}

\author{
Yete Pélagie $^{1,2,}$, Togbe Alexis ${ }^{1}$, Yovo Franck ${ }^{1}$, Wotto Valentin ${ }^{1,2}$, Sohounhloue Dominique ${ }^{2}$ \\ ${ }^{1}$ Department of Chemistry, Faculty of Science and Technology, University of Abomey-Calavi, Abomey-Calavi, Benin \\ ${ }^{2}$ Department of Chemical Engineering-Processes, Polytechnic School of Abomey-Calavi, University of Abomey-Calavi, Abomey-Calavi, \\ Benin
}

\author{
Email address: \\ Pelagie.yete@yahoo.fr (Y. Pélagie), abobosfr@yahoo.fr (T. Alexis), yovofranck62@gmail.com (Y. Franck), \\ bommow@yahoo.fr (W. Valentin), csohoun@gmail.com (S. Dominique) \\ *Corresponding author
}

\section{To cite this article:}

Yete Pélagie, Togbe Alexis, Yovo Franck, Wotto Valentin, Sohounhloue Dominique. Nutritional Potential of Co-products of Two Species of Benin Cucurbits. American Journal of Physical Chemistry. Vol. 8, No. 4, 2019, pp. 75-81. doi: 10.11648/j.ajpc.20190804.12

Received: November 6, 2019; Accepted: November 27, 2019; Published: December 9, 2019

\begin{abstract}
In the perspective of sustainable development, which involves the use of all biomass, two oilseeds have been selected according to their potential interests: Citrullus lanatus and Lagenaria siceraria. The physico-chemical characterization (oil and extraction cake) has been done. Thus, for extracted oils, unsaturated fatty acids are in the majority with the predominance of oleic and linoleic acids ( 21.31 to $44.36 \%$ and 16.20 to $70.35 \%$ respectively). The study of unsaponifiable fractions revealed that: Citrullus lanatus oil contains $134 \mathrm{mg} / 100 \mathrm{~g}$ sterols (including $78.60 \% \beta$-sitosterol) and $83.9 \mathrm{mg} / 100 \mathrm{~g}$ tocopherols (including $73.7 \% \alpha$-tocopherol) and Lagenaria siceraria oil contains $124 \mathrm{mg} / 100$ sterols (including $58.14 \% \quad \beta$-sitosterol) and $76.4 \mathrm{mg} / 100 \mathrm{~g}$ tocopherols (including $66.9 \% \quad \alpha$-tocopherol). Phospholipids (0.39 and $0.40 \%$ respectively for Lagenaria siceraria and Citrullus lanatus) were quantified on the basis of phosphorus content. This study shows the nutritional value of oils through their compositions in essential fatty acids, their richness in phytosterols and tocopherols on the one hand and the ways in which co-products resulting from the extraction of selected seeds on the other hand are valued. Research showing the influence of stabilizing agents on the quality and stability of oils should be carried out to make their use easier. Tests of the use of these oils in the fields of cosmetics, pharmaceuticals, paints and polymer synthesis industries could be carried out.
\end{abstract}

Keywords: Biomass, Citrullus Lanatus, Lagenaria Siceraria, Chemical Characterization

\section{Introduction}

Our human societies are facing challenges that are recognized as vital [1]. These issues are those of the availability of resources, particularly water and energy, health, particularly in its relationship to food and the environment, and socio-cultural traditions. Addressing these challenges requires a strong mobilization of innovation capacities, with a determination to propose viable and sustainable responses [2]. Agriculture, and particularly the cereal professions, can and should play a role in determining the best options for addressing these issues and their treatment [3]. The valorization of biomass for chemistry and energy is motivated by the need to develop new sectors based on the identification of plant species adapted to these uses.
As a result, food seeds known and appreciated by African populations such as Cucurbitaceae species, commonly known as squash in the Republic of Congo, "pistachios" in Côte d'Ivoire or "Egusi" in Benin and Nigeria [4], are vegetable sources rich in protein and can thus constitute a solution to protein-caloric malnutrition. Cucurbits (Egusi) containing a large number of species are oil plants unconventional. Their seeds are widely used throughout the world in association with other foods to meet human protein and lipid needs. Previous studies on the ecobotanical characteristics [5] and fruit or seed yield [6] of species grown in West Africa have been widely published.

Very few studies on the nutritional aspects of the seeds of the different cucurbit species have revealed that the species Citrullus lanatus and Lagenaria siceraria have more 
interesting nutritional potential [7-9].

The oils extracted from Cucurbits are rarely studied in the literature. To our knowledge, no studies on the nutritional properties of co-products of cucurbit species in particular: Citrullus lanatus and Lagenaria siceraria (species more appreciated in Benin) have been carried out as in the case of conventional oils and cakes (coconut, palm, palm kernel, soya and their cakes). Thus, it is appropriate that the oils and cakes of Citrullus lanatus and Lageraria sceraria be characterized in order to enhance the value of the seeds of these species. This work entitled "Nutritional potential of coproducts of two species of cucurbits in Benin" therefore aims to fill this gap.

\section{Materials and Methods}

\subsection{Materials}

\subsubsection{Seeds}

The collection of the seed lot analysed was carried out in the North (Savalou) of Benin (West Africa). They were properly dried in the sun until the seeds "sounded". The seeds were separated from the husks, properly sorted and cleared of all impurities, then shelled and finely ground. The almonds were finally packaged at $25^{\circ} \mathrm{C}$ in aluminium foil before the oil was extracted.

\subsubsection{Oil}

The non-conventional oils were obtained by extracting the seeds (finely ground) in Soxhlet for 6 hours at a temperature of $70^{\circ} \mathrm{C}$. Traces of hexane were removed by rotavapor. The extracted oils were packaged in dark bottles and in an inert atmosphere of dinitrogen.

\subsection{Methods}

\subsubsection{Physico-chemical Characterization of Oils}

The water and volatile matter contents are determined according to standard NF T 60-201 and hexane extractives (oil content) by standard NF V03-924. The acidity, peroxide value and saponification value are determined respectively according to the protocol of standards NF T60-204, NF T60220, NF ISO 3657.

\subsubsection{Determination of the Mineral Elements of the Oils}

The mineral elements (N, P, Ca, Mg, Mn, Mn, Zn, Cu, Na) were determined by ICP (Inductively Coupled Plasma) after mineralization of the sample. The principle of PCI is based on atomic emission and emission phenomena occurring in a plasma. The very high temperature of the plasma (7000 to $10000 \mathrm{~K})$ compared to that of a flame $(1000 \mathrm{~K})$ allows a better dissociation of the chemical species. The samples are dissolved according to the dry digestion procedure. The Varian Vista spectrometer is equipped with a CCD (Coupled Charge Device) detector. The device (Jobin Yvon JY) was at the following wavelengths: $\lambda=214.914 \mathrm{~nm}$ for phosphorus and $\lambda=589.592 \mathrm{~nm}$ for sodium. The assays were carried out by performing a calibration that respects the conditions of the analyzed medium (matrix, acidity). The calculations were performed by interpolation with respect to the calibration range. The validation of analytical results is based on the analysis of internal reference samples (controls), the mineral content of which is known.

\subsubsection{Determination of Fatty Acid Composition by GPC}

i. Preparation of Methyl Esters of Fatty Acids

The methyl esters have been prepared according to the NF T60-233 standard protocol.

ii. Mass Composition of Fatty Acids

To determine the fatty acid composition, $1 \mu \mathrm{L}$ of a hexane methyl ester solution was injected into an Agilent $6890 \mathrm{HP}$ series GC (Agilent, USA) equipped with an INNOWAX column (Agilent, USA), 30m long, $0.32 \mathrm{~mm}$ internal diameter and a $0.25 \mu \mathrm{m}$ film thickness. The injector was in split mode, ratio $1 / 80$ at $250^{\circ} \mathrm{C}$. The carrier gas was helium at a flow rate of $1.5 \mathrm{~mL} / \mathrm{min}$. The flame ionization detector was at $270^{\circ} \mathrm{C}$. The furnace temperature was programmed as follows: $150^{\circ} \mathrm{C}$ for 3 minutes followed by an increase of $3^{\circ} \mathrm{C} / \mathrm{min}$ to $220^{\circ} \mathrm{C}$ (26.3mm) which was kept constant until the end of the acquisition (35.3mn).

Peak identification was done by comparing the retention times of methyl esters of fatty acids of vegetable oils such as olive oil, sunflower oil and palm oil, injected under the same operating conditions. In order to verify the reproducibility of the results, each injection was repeated three times under the same operating conditions.

\subsubsection{Determination of Total Oil Sterols}

i. Determination of the unsaponifiable content

Unsaponifiable contents were determined using the IUPAC method [10].

ii. Preparation of the sterol fraction

To determine the total sterols, $0.5 \mathrm{~g}$ of oil, $1 \mathrm{~mL}$ of cholesterol and $5 \mathrm{~mL}$ of alcoholic $\mathrm{KOH}$ were introduced into a flask with 2 grains of pumice stone and refluxed for 15 min. $5 \mathrm{ml}$ of ethanol are then introduced into the flask from the top of the refrigerant. $10 \mathrm{~mL}$ of this solution are introduced into a chromatography column filled with aluminum oxide $(0.063<\mathrm{I}<0.2 \mathrm{~mm})$. Elutions were made successively with $5 \mathrm{ml}$ ethanol and $30 \mathrm{~mL}$ diethyl ether. The fraction obtained was after evaporation of the solvent, redissolved in $1 \mathrm{~mL}$ of chloroform.

iii. Preparative CCM of the sterol fraction

$20 \mu \mathrm{L}$ of a cholesterol standard solution and $400 \mu \mathrm{L}$ of the unsaponifiable oil fraction were successively deposited using a Linomat IV-Y CAMAG applicator (Merck, Ref. 022-786) on a silica plate 60 (Alltech, $20 \times 10 \mathrm{~cm}, 250 \mu \mathrm{m}$ thick). The elution was made by a chloroform/diethylether mixture $(90 / 10, \% \mathrm{v} / \mathrm{v})$. The part containing the cholesterol deposit was revealed by nebulizing a $\mathrm{Cu}^{++} / \mathrm{H}_{3} \mathrm{PO}_{4}$ mixture $(1 / 1, \% \mathrm{v} / \mathrm{v})$ and baking at $180^{\circ} \mathrm{C}$ for $10 \mathrm{~min}$.

The sterol band corresponding to the cholesterol spot was scraped off and the sterols were desorbed in chloroform $(10 \mathrm{~mL} / \mathrm{g}$ silica $)$ at room temperature under magnetic agitation for $5 \mathrm{~min}$. Once the silica became transparent, a Millipore filter filtration $(0.45 \mu \mathrm{m}$, Ref. SLFH $013 \mathrm{NL})$ allowed the total sterols to be recovered without solid 
contaminants.

iv. Sterol composition and content

$1 \mu \mathrm{L}$ of this sterol fraction was injected with GPC to determine the sterol content of the oil. The sterol analysis was performed under isothermal conditions $\left(285^{\circ} \mathrm{C}\right)$ in a GPC CG 8000 apparatus (Fisons Instruments) equipped with a SAC-5 column (Sigma-Aldrich, USA), (length 30m, $0.25 \mathrm{~mm}$ internal diameter and $0.25 \mu \mathrm{m}$ film thickness). The temperature of the flame ionization detector is maintained at $300^{\circ} \mathrm{C}$ and that of the injector in split mode, ratio $1 / 100$ at $300^{\circ} \mathrm{C}$. The integration of the peaks was done using a Merck D2000 integrator. The carrier gas was helium $(1.5 \mathrm{~mL} / \mathrm{min})$. To identify the peaks, we injected standards of cholesterol, $\beta$ sitosterol and stigmasterol (Sigma quality products, concentration of $1 \mathrm{mg} / \mathrm{mL}$ ). In order to verify the reproducibility of the results, each injection was repeated three times under the same operating conditions.

\subsubsection{Determination of Tocopherol Composition and Content by HPLCUV}

The analysis of oil tocopherols was performed by HPLC in the normal phase. A solution of $20 \mathrm{mg}$ oil per $\mathrm{mL}$ hexane and isopropanol (99: 1) was filtered through a millipore filter with a diameter of $0.45 \mu \mathrm{m}$ The device and its accessories (pump, injector, detector) are products of Agilent 1100 Series (France), comprising a quaternary pump, a manual injector with a $20 \mu \mathrm{L}$ injection loop and a DAD detector (with diode strips). The column was of type Luna Si $60,5 \mu \mathrm{m}, 4.6 \mathrm{x}$ $250 \mathrm{~mm}$ (Phenomenex, France). The solvent mixture under isocratic conditions was composed of hexane and isopropanol for HPLC (99: 1, \% v: v). The column flow rate was $1 \mathrm{~mL} / \mathrm{min}$ and the pressure 33 bar with a DAD detector at $295 \mathrm{~nm}$ wavelength. The peaks were identified by injecting tocopherol standards (Sigma aldrich products). The calibration curves were plotted using a dilution range of 0.3 to $8 \mu \mathrm{L} / \mathrm{mL}$.

\section{Results and Discussion}

\subsection{Physical and Chemical Characteristics of the Extracted Oils}

The physico-chemical characteristics of the extracted oils are presented in Table 1. They are compared to other oils commonly used in Benin for various applications. The oil contents (51.20 and $53 \%$ respectively for citrullus lanatus and lagenaria siceraria) are higher than those of cotton and groundnut oils [11]. These values are consistent with those obtained by [12]. Compared to the standards and some parameters of these oils (Table 1), it appears that the extracted oils meet all the quality criteria that would give them a good application under less expensive conditions [13-15].

\subsubsection{The Refractive Index (IR) and Iodine Index (ID)}

The refractive index shows a low dispersion of values for both oils. This table shows a difference between the iodine indices according to the oils. The two indices IR and ID are important criteria for identifying oils. According to Wolff cited in [16], there is a close relationship between the iodine index and the refractive index. For a non-polymerized, unoxidized oil, the two indices vary in the same direction. This allows oils to be classified as non-drying oils (ID $<100$ and $1.467<\mathrm{IR}<1.472)$, semi-siccative oils $(100<\mathrm{ID}<130$ and $1.470<\mathrm{IR}<1.478$ ) and drying oils (ID $>130$ and $1.481<\mathrm{IR}<1.482$ ). The examination of Table 1 shows that this report is not always respected. But the results obtained show a clear distinction between lagenaria siceraria oils (IR = 1.23 ; ID $=100.54$ ) and citrullus lanatus oils ( $\mathrm{IR}=1.36$; ID = 112.8). The refraction indices obtained with the oils analysed comply with the standards of the codex alimentarius. These high iodine index values can be explained by low oxidation of unsaturated fatty acids.

\subsubsection{The Peroxide Value and the Acid Value}

When an oil is not stored properly, its quality can deteriorate in various ways, but most often by hydrolysis or oxidation. In this case, it becomes unfit for consumption. Thus, the peroxide value which makes it possible to assess the degree of oxidation of an oil and the acid value which measures the quantity of free fatty acids resulting from triglyceride hydrolysis reactions are two quality criteria for reporting on the condition of an oil. The values of the peroxide indices obtained for the different oils (Table 1) comply with the standards of the codex alimentarius, which sets the value below $10 \mathrm{mEq}$ of peroxides $/ \mathrm{kg}$ of oil. This means that the oils analysed are very poorly oxidised. This low oxidation would be due to the extraction conditions which can cause a low oxidation of unsaturated fatty acids leading to their increase. This would justify the high values of the iodine indices obtained. From an acidity point of view, the values of the acid indices obtained in Table 1 range from $1.04 \pm 0.05$ (Lagenaria siceraria) to $1.20 \pm 0.03$ (Citrullus lanatus). However, according to the codex alimentarius, an oil of good quality must have little or no acidity. However, no sample analysed has zero acidity, but the results obtained with the oils still comply with codex standards.

\subsubsection{The Saponification Index}

The saponification index indicates the fatty acid content (esterified and free) of an oil. These values are 197.29 \pm 0.32 $\mathrm{mg} \mathrm{KOH} / \mathrm{g}$ (Lagenaria siceraria) and $195 \pm 0.21 \mathrm{mg} \mathrm{KOH} / \mathrm{g}$ (Citrullus lanatus) and therefore compatible with a predominance of $\mathrm{C} 18$ fatty acids. These values are similar to those obtained for vegetable oils such as soybean (189195mgKOH/g-oil), peanut (187-196 mg KOH/g-oil) and cotton (189-195 mg KOH/g-oil [17]. These values are higher than those obtained by [18]. The strong saponification indices observed would justify a possible use of these oils in soap making.

\subsubsection{Content of Unsaponifiable Substances}

The unsaponifiable contents are close (1.58) for Lagenaria siceraria oil and (1.65) for Citrullus lanatus oil. The study of their unsaponifiable fractions has shown that they have, in accordance with their high unsaponifiable content, high 
levels of sterols and especially tocopherols, which guarantee good resistance to oxidation. The exceptional phospholipid contents of the oils are comparable to that of rapeseed oil, one of the richest in phospholipids [19].

Consequently, the physical and chemical properties of the oils presented in Table 1 are generally in agreement with the bibliographic data for the results that can be compared.

Table 1. Chemical characteristics of the extracted oils.

\begin{tabular}{lll}
\hline Characteristis (g/100g-MS) & $\boldsymbol{C}$. $\boldsymbol{l}$ & $\boldsymbol{L} \boldsymbol{S}$ \\
\hline Oil content (\%-MS) & $51.20 \pm 0.22$ & $53 \pm 0.20$ \\
Acidity (\%-oleic) & $1.20 \pm 0.30$ & $1.04 \pm 0.50$ \\
Acid value (mg KOH/g) & $1.98 \pm 0.01$ & $2.56 \pm 0.01$ \\
saponification index (mg de KOH/g-oil) & $195.29 \pm 0.21$ & $197.29 \pm 0.32$ \\
Refractive index & $1.36 \pm 0.32$ & $1.23 \pm 0.32$ \\
Iodine index (g iodine / 100g oil) & $112.8 \pm 0.45$ & $100.54 \pm 0.50$ \\
Peroxide value (meq d'O2/Kg oil) & $0.99 \pm 0.02$ & $1.06 \pm 0.01$ \\
unsaponifiable (\%) & $1.65 \pm 0.00$ & $1.58 \pm 0.00$ \\
Total phosoholipids & $0.53 \pm 0.15$ & $0.35 \pm 0.25$ \\
\hline
\end{tabular}

C. 1: Citrullus lanatus; LS: Lageraria siceraria

\subsection{Fatty Acid Composition of Oils}

The levels of capric, lauric, myristic, palmitic, stearic, oleic, linoleic and in the analyzed oils are grouped in Table 2. The results obtained show profiles that are often specific to each type of oil. Gas chromatographic analysis of the total methyl esters of the fatty substances of the investigated seeds reveals the presence of three main fatty acids: palmitic acid (C16: 0), oleic acid (C18: 1) and linoleic acid (C18: 2). These oils have comparable profiles, although sometimes the percentages vary. However, we can see that these oils are very nutritious in view of their content of essential fatty acids (oleic and linoleic acid). The profile shows on the one hand the predominance of oleic, linoleic, palmitic acid and on the other hand a small percentage of myristic acid. In general, these results support the standards set by FAO. From the composition of the extracted oils, it appears that unsaturated fatty acids are strongly represented compared to saturated fatty acids which are practically only represented by palmitic acid. This high richness in unsaturated fatty acids could make oils of unsaturated types. Like olive, soybean, cotton, cotton, sunflower and groundnut oils, the oils studied are characterized by a majority presence of fatty acids with 18 carbon atoms. They could be used in various fields of food, cosmetics and soap-making due to their fatty acid composition and their physico-chemical characteristics.

Table 2. Fatty acid composition of extracted oils.

\begin{tabular}{lll}
\hline Fatty acids (\%) & $\boldsymbol{C} . \boldsymbol{l}$ & $\boldsymbol{L} . \boldsymbol{s}$ \\
\hline Myristic acid (C14: 0) & $2.53 \pm 0.38$ & $3.76 \pm 0.33$ \\
Palmitic acid (C16: 0) & $15.35 \pm 0.48$ & $12.05 \pm 0.19$ \\
Stearic acid (C18: 0) & $11.77 \pm 0.01$ & $9.48 \pm 0.01$ \\
Oleic acid (C18: 1, n-9) & $20.31 \pm 0.02$ & $14.04 \pm 0.03$ \\
Linoleic acid (C18: 2, n-9, 12) & $49.20 \pm 0.00$ & $60.10 \pm 0.01$ \\
Linolenic acid (C18:3, n-9, 12, 15) & $0.42 \pm 0.22$ & $0.15 \pm 0.00$ \\
Arachidic acid (C20: 0) & $0.14 \pm 0.01$ & $0.39 \pm 0.01$ \\
Gadoleic acid (C20: 1, n-9) & $0.28 \pm 0.02$ & $0.03 \pm 0.00$ \\
\hline
\end{tabular}

\subsection{Sterol and Tocopherol Profile of Oils}

\subsubsection{Sterol Content}

This family of compounds, especially $\beta$-sitosterol, helps to fight cardiovascular disease by reducing intestinal cholesterol adsorption [20]. $\beta$-sitosterol is the majority sterol followed by stigmasterol (Table 3). The total sterol contents (124 to 134 $\mathrm{mg} / 100 \mathrm{~g}$ oil) are in the same order of magnitude as those of olive oil (119-268 mg/100g), groundnut and palm oil (127171 and 123-140 mg/100g respectively) [21]. However, based on the results obtained, several ways of recovering the oils are possible:

1. In oncology: some sterols are reported to have anticancer activities and inhibit colon, rectal and lung cancers.

2. In the diet, a phytosterol supplement would have a cholesterol-lowering effect and thus limit the risk of cardiovascular disease.

3. And in cosmetology: sterols are used in many products with anti-inflammatory activities, or to repair skin damage and shampoos.

Table 3. Composition of the sterols fraction of extracted oils.

\begin{tabular}{lll}
\hline Constituents & $\boldsymbol{C} . \boldsymbol{l}$ & $\boldsymbol{L} . \boldsymbol{s}$ \\
\hline Campesterol (\%) & $3.53 \pm 0.03$ & $11.56 \pm 0.38$ \\
Lanosterol (\%) & $0.01 \pm 0.00$ & $0.15 \pm 0.00$ \\
$\Delta 5$-avenasterol (\%) & $5.35 \pm 0.22$ & $7.14 \pm 0.19$ \\
Stigmasterol (\%) & $12.51 \pm 0.04$ & $23.01 \pm 0.02$ \\
$\beta$ - sitosterol (\%) & $78.60 \pm 0.50$ & $58.14 \pm 0.45$ \\
total Sterols (mg/100g) & $134.00 \pm 0.32$ & $124.00 \pm 0.45$ \\
\hline
\end{tabular}

\subsubsection{Tocopherol Content}

Tocopherols and tocotrienols (tocols) are aromatic compounds with a chromanol ring (the carbon atom 6 carries a hydroxyl group) substituted by a chain with 3 condensed isopentenic units. Tocotrienols are rarely found in oils, except in the case of palm oil. Tocopherols, more present, although in minor fraction, are interesting because of their antioxidant and also vitaminic properties, mainly due to $\alpha$ tocopherol (vitamin E) [22]. This vitamin, whose biological properties are numerous, is used in several fields, particularly in cosmetology, and in several fields related to medicine: cardiology, anti-inflammatory drugs, oncology. The results obtained are summarized in Table 4. Tocopherols, mainly $\alpha$ tocopherol are the main compounds. We can also note the presence of $\delta$-tocotrienol, rather rare in vegetable oils. $\delta$ tocopherol, the most effective antioxidant, is present in all the oils studied.

Table 4. Composition of the tocopherols and tocotrienols in extracted oils.

\begin{tabular}{lll}
\hline Constituents & $\boldsymbol{C} . \boldsymbol{l}$ & $\boldsymbol{L} . \boldsymbol{s}$ \\
\hline$\delta$-tocotrienol $(\%)$ & $0.70 \pm 0.01$ & $0.66 \pm 0.01$ \\
$(\beta+\gamma)$ - tocotrienol (\%) & $1.44 \pm 0.00$ & $1.34 \pm 0.00$ \\
$\alpha$ - tocotrienol $(\%)$ & $1.01 \pm 0.02$ & $1.00 \pm 0.01$ \\
$\delta$-tocopherol $(\%)$ & $0.83 \pm 0.11$ & $1.05 \pm 0.10$ \\
$(\beta+\gamma)$-tocopherol (\%) & $22.33 \pm 0.10$ & $29.05 \pm 0.10$ \\
$\alpha$-tocopherol $(\%)$ & $73.70 \pm 0.22$ & $66.90 \pm 0.33$ \\
total Tocopherols $(\mathrm{mg} / 100 \mathrm{~g})$ & $83.90 \pm 0.30$ & $76.4 \pm 0.38$ \\
\hline
\end{tabular}




\subsection{Extraction Cakes}

\subsubsection{Mineral Element Content of Extraction Cakes}

Table 5 presents the mineral element composition of the extraction cakes in the seeds studied. The main minerals are phosphorus, nitrogen and potassium. The relatively high levels of N, P, K in Citrullus lanatus oilcake may favour its use in fertilizer formulations. In general, the mineral element composition of our extraction cakes is low compared to that of delipidated soybean, rapeseed, cotton, groundnut and palm nut cakes [23]. The proportions of N, P, K of Citrullus lanatus are higher than those of Lagenaria siceraria. This difference suggests the use of Citrullus lanatus oilcake as a replacement for chemical fertilizers in agriculture. These results show that oilcake can be a potential source of major and minor mineral elements, and can therefore be used to partially fill food and/or feed.

Table 5. Minerals elements of oilcakes.

\begin{tabular}{lll}
\hline Constituents & $\boldsymbol{C} . \boldsymbol{l}$ & $\boldsymbol{L} . \boldsymbol{s}$ \\
\hline totaux mineral & $9.40 \pm 0.00$ & $6.30 \pm 0.00$ \\
$\mathrm{~N}(\%)$ & $6.18 \pm 0.01$ & $3.36 \pm 0.02$ \\
$\mathrm{P}(\%)$ & $1.23 \pm 0.00$ & $0.88 \pm 0.02$ \\
$\mathrm{~K}(\%)$ & $1.28 \pm 0.00$ & $0.85 \pm 0.01$ \\
$\mathrm{Mg}(\%)$ & $0.48 \pm 0.00$ & $0.57 \pm 0.00$ \\
$\mathrm{Ca}(\%)$ & $0.13 \pm 0.01$ & $0.41 \pm 0.01$ \\
$\mathrm{Na}(\%)$ & $0.03 \pm 0.00$ & $0.12 \pm 0.00$ \\
\hline
\end{tabular}

\subsubsection{Organic Matter Content of the Oilcake}

The organic matter content of the extracted oilcake presented in Table 6 reflects their digestive character and testifies to their possible use as second-generation biofuels. From the analysis of this table, it appears that the two seeds studied have a significant variation in their respective chemical composition. The humidity levels are all below $9 \%$ which should encourage their storage. Generally speaking, we can see on this table that proteins constitute the main component of the two meals while the proportions of the other components are variable. The total protein contents of Citrullus lanatus and Lagenaria siceraria are comparable to the data in the literature [24]. These values are lower than those of soybean meal (36-53\% MS meal). The protein proportions of Citrullus lanatus are comparable to those of rapeseed and sunflower oilcake (20-25\%MS). If we consider each meal individually, Lagenaria siceraria has the highest content of crude fibre $(15.50 \% \mathrm{MS}$ meal) and lignin (8.90\%MS meal). The high proportions of starch and total sugars are indicative of the digestive character of the cakes studied and their use in animal feed [25]. Oilcake can be used as an energy source for some animals as long as it is not subject to rancidity. These exceptional levels could be explained by high proportions of polar lipids and/or a particular position of these lipids in the plant matrix. It is likely that polar lipids, especially phospholipids, are not extractable with hexane and require a prior acid attack to destroy cell walls. Nutrient-rich cakes could be used as livestock feed. However, they would constitute a lignocellulosic feedstock for second-generation bioethanol [26].
Table 6. Organic matter content of cakes.

\begin{tabular}{lll}
\hline characteristics $(\mathbf{g} / \mathbf{1 0 0 g}-\mathbf{M S})$ & $\boldsymbol{C} . \boldsymbol{l}$ & $\boldsymbol{L} . \boldsymbol{s}$ \\
\hline Total organic matter & $90.16 \pm 0.33$ & $98.96 \pm 0.32$ \\
Total proteins & $39.64 \pm 0.16$ & $37.15 \pm 0.13$ \\
Cellulose Wende & $12.50 \pm 0.50$ & $15.50 \pm 0.45$ \\
Lignins & $4.90 \pm 0.00$ & $8.90 \pm 0.01$ \\
Lignocellulose & $10.00 \pm 0.22$ & $16.24 \pm 0.22$ \\
Hemicellulose & $19.80 \pm 0.01$ & $20.13 \pm 0.02$ \\
Starch starch & $62.90 \pm 0.36$ & $70.45 \pm 0.50$ \\
Total sugars & $35.00 \pm 0.10$ & $33.45 \pm 0.00$ \\
\hline
\end{tabular}

\subsection{Amino Acids from Extraction Cakes}

Table 7 gives the amino acid composition of the extraction cakes. The levels of essential amino acids for humans (isoleucine, leucine, lysine, methionine, phenylalanine, treonine, tryptophan, valine and histidine), are in the range of $1.54-2.05 \%$ MS cakes for leucine. The contents for other essential amino acids are in the range of $0.90-1.72 \%$ MStourteau. However, the methionine contents are low (0.50 $0.64 \%$ MS oilcake). The amino acid compositions of the seeds are comparable to that of groundnuts [27]. These data confirm the nutritional value of seeds and their nutritional uses.

Table 7. Amino acids composition of extraction cakes.

\begin{tabular}{lll}
\hline Amino acids (\% MS - cakes) & $\boldsymbol{C} . \boldsymbol{l}$ & $\boldsymbol{L} . \boldsymbol{s}$ \\
\hline Valine & $1.11 \pm 0.00$ & $2.33 \pm 0.01$ \\
Isoleucine & $0.93 \pm 0.01$ & $1.66 \pm 0.00$ \\
Leucine & $1.54 \pm 0.00$ & $2.05 \pm 0.03$ \\
Lysine & $0.64 \pm 0.00$ & $0.14 \pm 0.00$ \\
Tyrosine & $0.72 \pm 0.02$ & $1.02 \pm 0.03$ \\
Methionine & $0.64 \pm 0.01$ & $0.50 \pm 0.00$ \\
Phenylalanine & $1.25 \pm 0.00$ & $2.01 \pm 0.01$ \\
Arginine & $2.20 \pm 0.15$ & $1.75 \pm 0.01$ \\
Serine & $0.99 \pm 0.00$ & nd \\
Histidine & $0.49 \pm 0.01$ & $1.40 \pm 0.03$ \\
Glycine & $n d$ & $3.04 \pm 0.00$ \\
Alanine & $1.13 \pm 0.00$ & $2.34 \pm 0.02$ \\
glutamic acid & $3.73 \pm 0.02$ & $1.16 \pm 0.01$ \\
Aspartic acid & $1.37 \pm 0.00$ & $2.33 \pm 0.03$ \\
Treonine & $0.90 \pm 0.00$ & nd \\
Proline & $1.33 \pm 0.01$ & nd \\
\hline
\end{tabular}

nd= not detected

\section{Conclusion}

This work is a contribution to the characterization of coproducts of Citrullus lanatus and Lagenaria siceraria from Benin. Fat contents and chemical characteristics are reported. The data obtained are also in compliance with standards and show their good qualities and possible uses in several areas such as food, soil amendment... etc. These species are of particular nutritional interest, given their chemical composition and nutritional potential.

The predominance of unsaturated fatty acids such as oleic acid and linoleic acid is compatible with the values obtained for iodine and saponification indices and justifies the liquid aspect of oils at ordinary temperature. This study has updated the data in the literature and should support the agri-food and 
socio-economic interest of the species studied, which would constitute an important source of organic substances (proteins and lipids) and mineral substances (phosphorus, calcium, potassium, sodium, magnesium).

The development of forest resources for industrial purposes can contribute to the protection of our threatened forests. Indeed, the preservation of standing species through diversification and greater valorisation of their by-products can promote their development.

It would be interesting to set up a complete seed fractionation process to produce certain functional ingredients. These ingredients must be tested in food formulations to assess their sensory, nutritional and economic added value. This idea of fractionation could also be applied to other seeds that are widely used and known for their nutritional potential.

\section{References}

[1] Adjanonhoun, E., Souza de, S., Sinsin, B. (2001). Rapport du Bénin. Compte rendu de la première réunion du Réseau "Espèces Ligneuses Médicinales", Station IITA Cotonou, Bénin. pp. 4-10.

[2] Dacosta, Y. (2003). Les phytonutriments bioactifs. (Ed). Paris; $317 \mathrm{p}$.

[3] Mvoula Tsieri, M., Silou, T., Tremolieres, A. (2005). Nature et composition des classes de lipides de quatre espèces de curcurbitacées alimentaire du Congo Brazzaville. Rivist Ital Sostanse Grasse; 82: 140-144.

[4] Zoro Bi, I., Koffi K. K., Dje Y. (2003). Caractérisation botanique et agronomique de trois espèces de cucurbits consommées en sauce en Afrique de l'ouest: Citrullus sp., Cucumeropsis manii, Lagenaria siceraria. Biotechnol. Agron. Soc. Environ. 7, p. 187-199.

[5] Vodouhe, R. S., Achigan Dako, G. E., Adjakidje, V. (2001). Observation de la diversité génétique des Egusi collectées au Bénin et au Togo. Actes 2 de l'Atelier Scientifique Sud et Centre, Niaouli. Institut National des Recherches Agricoles du Bénin, p. 53-61.

[6] Adodo, K., Elolo, O., Idès, B., Ayélé, C., Yao, B., Courdjo, L. (2015). Caractérisations chimiques et physico-chimiques des graines de Cucurbitacées du Togo: concombre amer (cucumeropsis edulis Hook. f.) et melon à pistache (Citrullus lanatus Var). J. Soc. Ouest-Afr. Chim, 040: 1-7.

[7] Akpambang, V. O. E., Amo, I. A., Izuagie, A. A. (2008). Comparative compositional analysis on two varieties of melon (Colocynthis citrullus and Cucumeropsis edulis) and a variety of almond (Prunus amygdalus). Research Journal of Agriculture and Biological Sciences; 4 (6): 639-642.

[8] Djenontin, S. T. Etudes de graines oléagineuses du Bénin: Caractérisation chimique. Fractionnement et activité biocide; 2006. Thèse de doctorat.

[9] De Oliveira Sousa, A. G., Fernandes, D. C., Alves, A. M., De Freitas, J. B., et Naves, M. M. V. (2011). Nutritional quality and protein value of exotic almonds and nut from the Brazilian savanna compared to peanut. Food Research International; 44 (7): 2319-2325.
[10] IUPAC Section 2: Oils and fats. In C. Paquot \& A. Hautfenne (Eds.), Standard Methods for the analysis of oilseeds, fats and derivatives (7th revised and enlarged edition). Oxford: International Union of Pure and Applied Chemistry, Blackwell Scientific Publications., 1987.

[11] Souci, S. W., Fachmann, W., Kraut H. (2000). La composition des aliments. Tableaux des Valeurs nutritionnelles. (6e édition) revue et complétée. Med pharm Scientific Publishers, CRC Press, Boca Raton.

[12] Wotto, D. V., N'dayishimiye, V., Yété, P., Sessou, P., Agbangnan, P., Sohounhloué, D. (2015). Physico-chemical characterization of oil and defatted meal from anacardium occidentale acclimated to teval in northen benin. World Journal of Pharmacy and Pharmaceutical Sciences. Volume 4, Issue 11, 1912-1920.

[13] Sidohounde, A., Nonviho, G., Djenontin, S. T., Agbangnan, P., Paris, C., \& Sohounhloue, D. C. (2015). Physico-Chemical Characterization of Vegetable Oil and Defatted Meal from Two Varieties of Cyperusesculentus from Benin. Chem J, 4, 17.

[14] Babatunde, O. A. \& Bello, G. S. (2016). Comparative assessment of some Physicochemical Properties of Groundnut and Palm Oils Sold Within Kaduna Metropolis, Nigeria. IOSR Journal of Applied Chemistry. 9 (11), 2278-5736.

[15] Benatti, P., Peluso, G., Nicolai, R., Calvani, M. (2004). Polyunsaturated fatty acids: Biochemical, nutritional and epigenetic properties. Journal of the American College of Nutrition 23, 281-302.

[16] Kouwanou, C. S., Montcho, P. S., Agbangnan Dossa, C. P., Adjou, E., Wotto, V. D., Sohounhloué, D. C. K. (2018). Physico-Chemical Characterizations and Fuel Potential Assessment of Chrysophyllum albidum Fruits from Benin. American Journal of Physical Chemistry. Vol. 7, No. 3, pp. 5054. doi: 10.11648/j.ajpc.20180703.12.

[17] . Evans, J. C., Kodali, D. R., Addis, P. B. (2002). Optimal tocopherol concentrations to inhibit soybean oil oxidation. Journal of the American Oil Chemists Society. 79: 47-51.

[18] Bocar, K. M., Sidi, O. A., Baïdy, B. L., Emmanuel, B. (2011). Etude physico-chimique des huiles consommées en mauritanie science lib. Volume $4, \mathrm{~N}^{\circ} 120101$ ISSN 2111-4706.

[19] Akinhanmi, T. F., Atasie, V. N. (2008). Chemical composition and physicochemical properties of cashew nut (Anacardium occidentale) oil and cashew nut shell liquid. Journal of agricultural. Food and Environment Sciences; 2 (1).

[20] Sidohounde, A., Agbangnan Dossa, C. P., Nonviho, G., Montcho, S. P., Sohounhloue, D. C. K. (2018). Transesterification Reaction and Comparative Study of the Fuel Properties of Biodiesels Produced from Vegetable Oils: A Review. American Institute of Science: Chemistry Journal. Vol. 4, No. 4, pp. 79-90.

[21] Aremu, M. O., Olonisakin, A., Bako, D. A., Madu, P. C. (2006). Composition studies and physicochemical characteristics of cashew nut (Anacardium occidentale) flour. Pakistan Journal of Nutrition; 5 (4): 328-333.

[22] Aletor, O., Agdebe, J. O., Adeyeye, S. A., Aletor, V. A. (2007). Chemical and physiochemical characterization of the flour and oils from whole and rejected cashew nuts cultivated in southwest Nigeria. Pakistan Journal of Nutrition; 6 (1): 8993. 
[23] Djenontin, S. T., Dangou, J., Wotto, D. V., Sohounlhoue, K. C. D., Lozano, P., Pioch, D. (2006). Composition en acides gras, stérols et tocophérols de l'huile végétale non conventionnelle extraite des graines de jatropha curcas (euphorbiaceae) du Benin J. Soc. Ouest-Afr. Chim; 22: 59-67.

[24] Omosuli, S. V., Ibrahim, T. A., Oloye, D., Agbaje, R., JudeOjei, B. (2009). Proximate and mineral composition of roasted and defatted cashew nut (Anacardium occidentale) flour. Pakistan Journal of Nutrition; 8 (10): 1649-1651.

[25] Mehra, M., Pasricha, V. \& Gupta, R. (2015). Estimation of nutritional, phytochemical and antioxidant activity of seeds of musk melon (Cucumis melo) and water melon (Citrullus lanatus) and nutritional analysis of their respective oils. Journal of Pharmacognosy and Phytochemistry, 3 (6): 98-102.

[26] Mian-Hao, H. \& Yansong, A. (2007). Characteristics of some nutritional composition of melon (Cucumis melo hybrid "ChunLi") seeds. International Journal of Food Science and Technology, 42 (12): 1397-1401.

[27] Lee, C. F. \& Lin, J. Y. (1995). Amino acid sequences of trypsin inhibitors from the melon Cucumis melo Journal of Biochemistry, 118 (1): 18-22. 